\title{
Inbreeding depression in the wild
}

\author{
PETER CRNOKRAK* \& DEREK A. ROFF \\ Department of Biology, McGill University, 1205 Docteur Penfield Ave., Montreal, Quebec, Canada H3A 1B1
}

\begin{abstract}
Despite its practical application in conservation biology and evolutionary theory, the cost of inbreeding in natural populations of plants and animals remains to a large degree unknown. In this review we have gathered estimates of inbreeding depression $(\delta)$ from the literature for wild species monitored in the field. We have also corrected estimates of $\delta$ by dividing by $F$ (coefficient of inbreeding), to take into account the influence that the variation in $F$ will have on $\delta$. Our data set includes seven bird species, nine mammal species, four species of poikilotherms (snakes, fish and snails) and 15 plant species. In total we obtained 169 estimates of inbreeding depression for 137 traits; 81 of those estimates included estimates of $F$. We compared our mammalian data (limited to those traits related to juvenile mortality) to the estimates for captive zoo species published by Ralls et al. (1988) to determine if, as predicted from the literature, natural estimates of inbreeding depression are higher than captive estimates. The mean $\delta \pm \mathrm{SE}$ (significantly different from zero and not corrected for $F$ ) for homeotherms was $0.509 \pm 0.081$; for poikilotherms, $0.201 \pm 0.039$; and for plants, $0.331 \pm 0.038$. Levels of inbreeding depression this high in magnitude will be biologically important under natural conditions. When we limited our data set to mortality traits for mammals and corrected for $F=0.25$ (as is the case for the Ralls et al. data set), we found a significant difference between the two data sets; wild estimates had a substantially higher mean cost of inbreeding at $F=0.25: 2.155$ (captive species: 0.314 ). Of the 169 estimates of $\delta, 90$ were significantly different from zero, indicating that inbred wild species measured under natural conditions frequently exhibit moderate to high levels of inbreeding depression in fitness traits.
\end{abstract}

Keywords: coefficient of inbreeding, fitness, inbreeding depression.

\section{Introduction}

Inbreeding depression is the decline in the value of a trait as a direct consequence of inbreeding (Wright, 1977; Shields, 1987). The most common estimates of inbreeding depression involve traits that are closely related to fitness, such as reproductive traits (e.g. number of eggs laid, number of young surviving), or metric traits indirectly associated with fitness (e.g. ejaculate volume, plant height). The reduction of fitness after close inbreeding can be caused by a number of genetic factors: the unmasking of recessive deleterious alleles (Lande, 1994; Lynch et al., 1995), increased homozygosity and/or reduced allozyme variability (Falk \& Holsinger, 1991; Brock \& White, 1992; Pray et al., 1994; Vrijenhoek, 1994). Whatever the genetic mechanism, inbreeding depression is a real phenomenon that has received a substantial amount of attention in the literature (Ralls \& Ballou, 1983, 1986; De Bois et al.,

*Correspondence. E-mail: crnokrak@bio1.lan.mcgill.ca
1990; Lacy et al., 1993; see Frankham, 1995a and Roff, 1997 for reviews).

Most of the literature concerning inbreeding depression has concentrated on domestic or captive-bred wild species (Ralls \& Ballou, 1986; for a review see Lacy et al., 1993) because of the obvious difficulties of making estimates on wild species in nature. One of the most comprehensive data sets is that of pedigrees from zoo populations (Ralls et al., 1988). Forty captive populations belonging to 38 species show an average increase in mortality of 33\% for inbred matings (Ralls et al., 1988). Ralls et al. (1988, p. 191) suggest that 'the total costs of inbreeding in natural populations are probably considerably higher', which would make the cost of inbreeding in natural populations of substantial evolutionary consequence. The implications of high levels of inbreeding depression to population extinction are obvious (Lande, 1988; Caro \& Laurenson, 1994; Caughley, 1994). However, the degree of inbreeding depression in wild populations remains controversial (see Frankham, 1995a for a discussion). The two most commonly suggested reasons why inbreeding effects in natural populations may not be significant are: (i) animals in the 
wild avoid close inbreeding, and therefore do not manifest the deleterious fitness effects; and (ii) even if inbreeding does occur, animals are able, either behaviourally or physiologically, to deal with the deleterious genetic effects before they are manifest on a phenotypic level, whereas captive species, because of the conditions of captivity, cannot respond in such a manner. Although evidence of inbreeding depression in wild species has been published (see Frankham, 1995a for a short review), the lack of a comprehensive review across species has led to the remaining scepticism about its existence in natural populations (Caro \& Laurenson, 1994).

The objective of the present study was to estimate the average inbreeding depression for wild species measured under natural conditions. We are concerned here not with whether inbreeding occurs in the wild (although we report the coefficient of inbreeding, $F$, for those studies for which it was available) but rather the consequences of inbreeding on characteristics of organisms living in the wild. Specifically, we attempt to answer two questions: (i) is inbreeding depression in wild populations of sufficient magnitude to be biologically important should inbreeding occur? and (ii) does the cost of inbreeding differ between natural and captive populations?

\section{Methods}

\section{The data set}

We obtained 169 estimates of inbreeding depression from the literature. The data set includes 35 species ( 20 animals, 15 plants) and 137 traits (see Appendix). We included only species that were sampled from wild populations or species that were artificially inbred in the laboratory, or glasshouse, for one generation and their progeny released, or grown, in the area from which their parents originated. Where more than one estimate was given for a particular trait, we included all estimates in the analysis.

To standardize relative differences in fitness traits, we used the coefficient of inbreeding depression $\delta$ (Lande \& Schemske, 1985):

$\delta=1 \quad\left(X_{\mathrm{I}} / X_{\mathrm{O}}\right)$,

where $X_{\mathrm{I}}=$ inbred trait value and $X_{\mathrm{O}}=$ outbred trait value. To standardize estimates of $\delta$ further, we changed traits such as juvenile mortality (where it is expected that $X_{\mathrm{O}}<X_{\mathrm{I}}$ ) to juvenile survivorship (so that $X_{\mathrm{O}}>X_{\mathrm{I}}$ ). This way all estimates are 'positive', and the a priori prediction is that outbred values should be greater than inbred ones. Certain traits (e.g. sperm abnormalities in lions) that could not be modified because they were not expressed as portions of a total, were not used in the analysis. We included traits that were either directly related to fitness, e.g. total number of eggs laid, or traits indirectly related to fitness, e.g. juvenile weight.

Because the magnitude of inbreeding depression will vary with the inbreeding coefficient of the inbred individuals studied, $F$ (Falconer, 1989), we corrected $\delta$ estimates by standardizing with respect to $F$. The change in trait value because of inbreeding is

$b=\left(\begin{array}{ll}X_{\mathrm{O}} & X_{\mathrm{I}}\end{array}\right) / F$,

where $b$ is the slope of the relationship between trait value and $F$. Because $X_{\mathrm{O}}$ will vary among traits, we scale by dividing throughout by $X_{\mathrm{O}}$ giving

$b_{X_{O}}=\left(1 \quad X_{\mathrm{I}} / X_{\mathrm{O}}\right) / F$.

Because $1-X_{\mathrm{I}} / X_{\mathrm{O}}$ is the measure of inbreeding depression, $\delta$, we can simplify the equation to

$b_{X_{0}}=\delta / F$.

Since $\delta=b_{X_{0}} F$, the standardized slope is equivalent to inbreeding depression when $F=1$. Therefore, dividing the estimates of $\delta$ by $F$ allows for a standardized comparison of the cost of inbreeding. We obtained 81 estimates of $F$ from 14 studies. We called the $F$-corrected data set $b_{X_{O}}$ (includes negative values because of $X_{\mathrm{O}}<X_{\mathrm{I}}$ ).

\section{Statistical analysis}

All statistical analyses were carried out using SYSTAT (Wilkinson, 1991). We divided the data set into estimates of $\delta$ that were significant and those that were nonsignificant, to determine how often significant levels of inbreeding depression were detected.

To determine if natural conditions increase inbreeding depression relative to captive conditions, we compared the mean inbreeding depression we obtained from the literature with the data set included in the Ralls et al. (1988) review of inbreeding depression in captive-bred populations of wild species. Ideally the most appropriate test would be a comparison between natural and captive conditions for the same traits in the same species (paired comparison). We were not able to conduct paired comparisons because of the lack of use of the same species between this and the Ralls et al. study. Ralls et al. (1988) calculated the slope of $\ln$ (survival) vs. inbreeding and then predicted the cost of inbreeding for a level of inbreeding of $F=0.25$. Because the Ralls et al. data set was limited to survival of offspring of mammals only, we limited our data set to traits directly related to 
survival in mammals. Our estimates were obtained from the $\delta$ data set and corrected for $F=0.25$. We used a Student's $t$-test to determine if significant differences exist between mean estimates of the cost of inbreeding at $F=0.25$ between the two data sets.

\section{Results}

\section{Magnitude of inbreeding depression}

Theory suggests that females should not mate with their closest relatives unless the cost of inbreeding is less than 0.33 (Smith, 1979). In addition, an increased probability of extinction occurs just below intermediate levels $(F=0.30-0.40)$ of inbreeding (Frankham, 1995b). We found very high mean estimates of inbreeding depression for species measured in the wild. For $\delta$ estimates, mean inbreeding depression ranged from 0.197 (poikilotherms) to 0.268 (homeotherms) (Table 1; 30\% of estimates $>0.33)$. In addition, mean $( \pm \mathrm{SE}) \delta$ estimates that were significantly different from zero were $0.509 \pm 0.081$ for homeotherms, $0.201 \pm 0.039$ for poikilotherms and $0.331 \pm 0.038$ for plants. Most of these estimates of inbreeding depression are sufficiently high in magnitude $(>0.33)$ to be considered biologically important (see Smith, 1979; Frankham, 1995b). In addition, most of the traits $(80 \%)$, are directly associated with fitness.

For $b_{X_{\mathrm{O}}}$ estimates, mean inbreeding depression corrected for $F$ ranged from 0.552 for plants to 0.818 for homeotherms (Table 1).

\section{Wild and captive comparisons of the cost of inbreeding at $\mathrm{F}=0.25$}

The comparison of our data set (limited to only those inbreeding depression estimates of mortality of mammals and corrected for $F=0.25$, i.e. $\delta / 0.25$ ) with that of Ralls et al. (1988) revealed a highly significant difference between mean estimates for juvenile mortality (our data set (mean $\pm \mathrm{SE}$ ): $n=9, \bar{x}=2.155 \pm 0.482$; Ralls et al. data set: $n=40, \quad \bar{x}=0.314 \pm 0.044 ; \quad t_{47}=7.687$, $P=0.0001$ ). Even without correcting for $F=0.25$, our estimate was significantly higher than the Ralls et al.

Table 1 Mean inbreeding depression and standard errors for homeotherms, poikilotherms and plants using the two estimates $\delta$ and $b_{X_{0}}$

\begin{tabular}{lccc}
\hline Species group & $\bar{\delta} \pm \mathrm{SE}$ & $\bar{b}_{X_{\mathrm{O}}} \pm \mathrm{SE}$ & $n(\delta), n\left(\bar{b}_{X_{\mathrm{O}}}\right)$ \\
\hline Homeotherms & $0.268 \pm 0.041$ & $0.818 \pm 0.472$ & 63,20 \\
Poikilotherms & $0.197 \pm 0.028$ & $0.661 \pm 0.121$ & 25,23 \\
Plants & $0.264 \pm 0.032$ & $0.552 \pm 0.106$ & 75,34 \\
\hline
\end{tabular}

estimate $\quad\left(\bar{x}=0.539 \pm 0.121 ; \quad t_{47}=2.061, \quad P=0.04\right)$. Although inbreeding depression normally ranges between 0 and 1 (unless the survival of inbreds exceeds that of outbreds), our calculated mean cost of inbreeding of 2.155 results from the correction using $F=0.25$. As predicted by Ralls et al. (1988), wild estimates of the cost of inbreeding at $F=0.25$ are substantially higher than captive estimates.

\section{Discussion}

We found that statistically significant levels of inbreeding depression in the wild are detected $\approx 54 \%$ of the time when species are known to be inbred. When significant, mean inbreeding depression (not corrected for the coefficient of inbreeding, $F$ ) ranged from 0.20 in poikilotherms to 0.51 in homeotherms. When corrected for $F$, mean inbreeding depression for all estimates ranged from 0.55 in plants to 0.82 in homeotherms. The analysis using only mammals revealed significantly greater estimates of the cost of inbreeding at $F=0.25$ from free-ranging mammals than estimates from captive populations (2.16 and 0.31 , respectively). Therefore, as predicted by Ralls et al. (1988), conditions experienced in the wild increase the cost of inbreeding (similar findings have been made for plants; reviewed by Roff, 1997).

Although we have demonstrated that the cost of inbreeding under natural conditions is much higher than under captive conditions, we lack sufficient data to determine which environmental factors cause such an increase. Inbreeding depression is typically more severe in harsher environments (Falk \& Holsinger, 1991; Hoffmann \& Parsons, 1991; Latter et al., 1995; for a review see Miller, 1994). Environmental factors such as unpredictable rainfall, fluctuating temperatures and limiting resources to feed young are all likely to have a significant effect on juvenile mortality. Weak inbred young that would normally die in the wild would most likely survive in captivity with veterinary assistance (Ralls et al., 1988). Some studies have shown that individuals with relatively low allozyme heterozygosity and/or with a high number of lethal equivalent alleles are much more susceptible to factors that may not affect "normal" individuals (Pierce \& Mitton, 1982; O'Brien et al., 1985; Mitton et al., 1986; Murphy et al., 1987; Ralls et al., 1988; Fritz \& Simms, 1992; for examples in which no effects are observed see review in Roff, 1997). Although most of our arguments suggest reasons why inbreeding depression will be higher in the wild, inbreeding depression in captivity can be biased upwards as a result of poor husbandry or as an artifact of captive breeding. It has been argued that a reduction in fitness traits is to be expected in animals that have greatly 
dissimilar genetic backgrounds (because of the breakdown of coadapted gene complexes), which may be a common occurrence in captive populations (Smith, 1979); in such cases outbreeding depression may have been misdiagnosed as inbreeding depression (Templeton, 1987). The ongoing debate concerning whether the seriously reduced reproductive capacity of cheetahs in captivity is caused by genetic factors or incorrect captive conditions, is a good example of the difficulty of determining the cause of low fitness even for an individual species (Caro \& Laurenson, 1994; Merola, 1994; O'Brien, 1994). However, poor husbandry techniques for captive species may increase inbreeding depression, which means that in a situation where an inbred population is maintained under ideal conditions, the inbreeding depression in survival will probably be lower than the Ralls et al. (1988) estimate of 0.31 , and will be substantially lower than our calculated mean of 0.539 .

There are a number of important implications of high levels of inbreeding depression in wild species. Populations that experience high levels of inbreeding and subsequent inbreeding depression may in future generations have significantly lower levels of inbreeding depression even if closely inbred, because of the purging of deleterious recessive alleles expressed during inbreeding (Wright, 1977; Lorenc, 1980; Bryant et al., 1990; Barrett \& Charlesworth, 1991; Ribble \& Millar, 1992; Hedrick, 1994). Nevertheless, although the expected effects of purging deleterious alleles have been documented to some extent (see Husband \& Schemske, 1996 for a review), the degree of purging is questionable (see Frankham, 1995a for a discussion), and an accelerated rate of inbreeding in populations can potentially drive a population towards extinction (Gilpin \& Soule, 1986). Although the susceptibility of most populations of animals and plants to high levels of inbreeding and inbreeding depression is poorly known, our results show that inbred organisms in the wild do exhibit inbreeding depression and that the costs of inbreeding in the wild are substantially higher than previously thought (Ralls et al., 1988). The importance of inbreeding depression for wild populations depends not only on the magnitude of the effect when it occurs but also the likelihood of inbreeding. Although high levels of inbreeding have been observed in some populations of animals and plants (Thornhill, 1993; Husband \& Schemske, 1996), much more data are needed to ascertain its frequency.

\section{References}

ALberts, S. C. AND ALtmanN, J. 1995. Balancing costs and opportunities: dispersal in male baboons. Am. Nat., 145, 279-306.
ARCESE, P. 1989. Intrasexual competition, mating system and natal dispersal in song sparrows. Anim. Behav., 38, 958-979.

ASHMAN, T. L. 1992. The relative importance of inbreeding and maternal sex in determining progeny fitness in Sidalcea oregana ssp. spicata, a gynodioecious plant. Evolution, 46, 1862-1874.

BARRETT, S. C. H. AND CHARLESWORTH, D. 1991. Effect of a change in the level of inbreeding on the genetic load. Nature, 352, 522-524.

BROCK, M. K. AND WHITE, B. N. 1992. Applications of DNA fingerprinting to the recovery program of the endangered Puerto Rican parrot. Proc. Natl. Acad. Sci. U.S.A., 89, 11,121-11,125.

BROWN, J. L. AND BROWN, E. R. 1998. Are inbred offspring less fit? Survival in a natural population of Mexican jays. Behav. Ecol., 9, 60-63.

BRYANT, E. H., MEFFERT, L. M. AND McCOMMAS, S. A. 1990. Fitness rebound in serially bottlenecked populations of the house fly. Am. Nat., 136, 542-549.

BUlGER, J. AND HAMILTON, W. J. III. 1988. Inbreeding and reproductive success in a natural chacma baboon, Papio cynocephalus ursinus, population. Anim. Behav., 36, 574-578.

BULMER, M. G. 1973. Inbreeding in the great tit. Heredity, 30, 313-325.

CARO, T. M. AND LAURENSON, M. K. 1994. Ecological and genetic factors in conservation: a cautionary tale. Science, 263, 485486.

CAUGHLEY, G. 1994. Directions in conservation biology. J. Anim. Ecol., 63, 215-244.

CHEN, X. 1993. Comparison of inbreeding and outbreeding in hermaphroditic Arianta arbustorum (L.) (land snail). Heredity, 71, 456-461.

DE BOIS, H., DHONDT, A. A. AND VAN PUIJENBROEK, B. 1990. Effects of inbreeding on juvenile survival of the Okapi Okapia johnstoni in captivity. Conserv. Biol., 54, 147-155.

DIETZ, J. M. AND BAKER, A. J. 1993. Polygyny and female reproductive success in golden lion tamarins, Leontopithecus rosalia. Anim. Behav., 46, 1067-1078.

DUDASH, M. R. 1990. Relative fitness of selfed and outcrossed progeny in a self-compatible, protandrous species, Sabatia angularis L. (Gentianaceae): a comparison in three environments. Evolution, 44, 1129-1139.

FALCONER, D. S. 1989. Introduction to Quantitative Genetics, 3rd edn. John Wiley and Sons, New York.

FALK, D. A. AND HOLSINGER, K. E. 1991. Genetics and Conservation of Rare Plants. Oxford University Press, New York.

FENSTER, C. B. 1991. Gene flow in Chamaecrista fasciculata (Leguminosae) II. Gene establishment. Evolution, 45, 410 422.

Frankham, R. 1995a. Conservation genetics. Ann. Rev. Genet., 29, 305-327.

FRANKHAM, R. 1995b. Inbreeding and extinction: a threshold effect. Conserv. Biol., 9, 792-799.

FRITZ, R. S. AND SIMMS, E. L. 1992. Plant Resistance to Herbivores and Pathogens: Ecology, Evolution and Genetics. Chicago University Press, Chicago.

GIBBS, H. L. AND GRANT, P. R. 1989. Inbreeding in Darwin's medium ground finches (Geospiza fortis). Evolution, 43, 1273-1284. 
GILPIN, M. E. AND SOULÉ, M. E. 1986. Minimum viable populations: the processes of species extinctions. In: Soulé, M. E. (ed.) Conservation Biology: the Science of Scarcity and Diversity, pp. 13-34. Sinauer Associates, Sunderland, MA.

GJERDE, B., GUNNES, K. AND GJEDREM, T. 1983. Effect of inbreeding on survival and growth in rainbow trout. Aquaculture, 34, 327-332.

GRANT, P. R. AND GRANT, R. 1995. The founding of a new population of Darwin's finches. Evolution, 49, 229-240.

GREENWOOD, P. J., HARVEY, P. H. AND PERRINS, C. M. 1978. Inbreeding and dispersal in the great tit. Nature, 271, $52-54$.

HARDER, L. D., THOMSON, J. D., CRUZAN, M. B. AND UNNASCH, R. S. 1985. Sexual reproduction and variation in floral morphology in an ephemeral vernal lily, Erythronium americanum. Oecologia, 67, 286-291.

HEDRICK, P. W. 1994. Purging inbreeding depression and the probability of extinction: full-sib mating. Heredity, 73, 363372.

HESCHEL, M. S. AND PAIGE, K. N. 1995. Inbreeding depression, environmental stress, and population size variation in scarlet gilia (Ipomopsis aggregata). Conserv. Biol., 9, 126-133.

HOFFMANN, A. A. AND PARSONS, P. A. 1991. Evolutionary Genetics and Environmental Stress. Oxford University Press, Oxford.

HOOGLAND, J. L. 1992. Levels of inbreeding among prairie dogs. Am. Nat., 139, 591-602.

HUSBAND, B. C. AND SCHEMSKE, D. W. 1996. Evolution of the magnitude and timing of inbreeding depression in plants. Evolution, 50, 54-70.

JAIN, S. K. 1978. Breeding system in Limnanthes alba: several alternative measures. Am. J. Bot., 65, 272-275.

JIMENEZ, J. A., HUGHES, K. A., ALAKS, G., GRAHAM, L. AND LACY, R.C. 1994. An experimental study of inbreeding depression in a natural habitat. Science, 266, 271-273.

JOHNSTON, M. O. 1992. Effects of cross and self-fertilization on progeny fitness in Lobelia cardinalis and L. siphilitica. Evolution, 46, 688-702.

KELLER, L. F., ARCESE, P., SMITH, J. N. M., HOCHACHKA, W. M. AND STEARNS, S. C. 1994. Selection against inbred song sparrows during a natural population bottleneck. Nature, 372, 356-357.

LACY, R. C., PETRIC, A. AND WARNEKE, M. 1993. Inbreeding and outbreeding in captive populations of wild animals. In: Thornhill, N. W. (ed.) The Natural History of Inbreeding and Outbreeding: Theoretical and Empirical Perspectives, pp. 352-374. University of Chicago Press, Chicago.

LANDE, R. 1988. Genetics and demography in biological conservation. Science, 241, 1455-1460.

LANDE, R. 1994. Risk of population extinction from fixation of new deleterious mutations. Evolution, 48, 1460-1469.

LANDE, R. AND SCHEMSKE, D. W. 1985. The evolution of self fertilization and inbreeding depression in plants. I. Genetic models. Evolution, 39, 24-40.

LATTER, B. D. H., MUlley, J. C., ReID, D. AND PASCOE, L. 1995. Reduced genetic load revealed by slow inbreeding in Drosophila melanogaster. Genetics, 139, 287-297.

LORENC, E. 1980. Analysis of fertility in inbred lines of mice derived from populations differing in the genetic load. Zwierzeta Lab., 17, 3-16.
LYNCH, M., CONERY, J. AND BUERGER, R. 1995. Mutation accumulation and the extinction of small populations. Am. Nat., 146, 489-518.

MADSEN, T., STILLE, B. AND SHINE, R. 1996. Inbreeding depression in an isolated population of adders Vipera berus. Biol. Conserv., 75, 113-118.

MEROLA, M. 1994. A reassessment of homozygosity and the case for inbreeding depression in the cheetah (Acinonyx jubatus): implications for conservation. Conserv. Biol., 8 , 961-971.

MILLER, P. S. 1994. Is inbreeding depression more severe in a stressful environment? Zool. Biol., 13, 195-208.

MITTON, J. B., CAREY, C. AND KOCHER, T. D. 1986. The relation of enzyme heterozygosity to standard and active oxygen consumption and body size of tiger salamanders, Ambystoma tigrinum. Physiol. Zool., 59, 574-582.

MURPHY, J. B., REHG, J. E., MADERSON, P. F. A. AND McCRADY, W. B. 1987. Scutellation and pigmentation defects in a laboratory colony of Western diamondback rattlesnakes (Crotalus atrox): mode of inheritance. Herpetologica, 43, 292-300.

O'BRIEN, S. J. 1994. The cheetah's conservation controversy. Conserv. Biol., 8, 1153-1155.

O'BRIEN, S. J., ROELKE, M. E., MARKER, L., NEWMAN, A., WINKLER, C. A., Meltzer, D. ET AL. 1985. Genetic basis for species vulnerability in the cheetah. Science, 227, 1428-1434.

PACKER, C. 1979. Inter-troop transfer and inbreeding avoidance in Papio anubis. Anim. Behav., 27, 1-36.

PIERCE, B. A. AND MitTon, J. B. 1982. Allozyme heterozygosity and growth in the tiger salamander, Ambystoma tigrinum. J. Hered., 73, 250-253.

POLANS, N. O. AND ALlARD, R. W. 1989. An experimental evaluation of the recovery potential of ryegrass populations from genetic stress resulting from restriction of population size. Evolution, 43, 1320-1324.

PRAY, L. A., SCHWARTZ, J. M., GOODNIGHT, C. J. AND STEVENS, L. 1994. Environmental dependency of inbreeding depression: implications for conservation biology. Conserv. Biol., 8, $562-568$.

PRICE, M. V. AND WASER, N. M. 1979. Pollen dispersal and optimal outcrossing in Delphinium nelsoni. Nature, 277, 294-297.

RAlls, K. AND BALlou, J. 1983. Extinction: lessons from zoos. In: Schonewald-Cox, C. M., Chambers, S. M., MacBryde, B. and Thomas, W. L. (eds) Genetics and Conservation: a Reference for Managing Wild Animal and Plant Populations, pp. 164-184. Benjamin/Cummings, Menlo Park, CA.

RALLS, K. AND BALLOU, J. 1986. Captive breeding programs for populations with a small number of founders. Trends Ecol. Evol., 1, 19-22.

RALlS, K., BALlOU, J. D. AND TEMPLETON, A. 1988. Estimates of lethal equivalents and the cost of inbreeding in mammals. Conserv. Biol., 2, 185-193.

RIBBLE, D. O. AND MILLAR, J. S. 1992. Inbreeding effects among inbred and outbred laboratory colonies of Peromyscus maniculatis. Can. J. Zool., 70, 820-824.

ROFF, D. A. 1997. Evolutionary Quantitative Genetics. Chapman \& Hall, New York.

ROSENFIELD, R. N. AND BIELEFELDT, J. 1992. Natal dispersal and inbreeding in the Cooper's Hawk. Wilson Bull., 104, 182-184. 
ROWLEY, I., RUSSELL, E. AND BROOKER, M. 1986. Inbreeding: benefits may outweigh the costs. Anim. Behav., 34, 939-941.

RUCKELSHAUS, M. H. 1995. Estimates of outcrossing rates and of inbreeding depression in a population of the marine angiosperm Zostera marina. Mar. Biol., 123, 583-593.

RYMAN, N. 1970. A genetic analysis of recapture frequencies of released young of salmon (Salmo salar L.). Hereditas, 65 , 159-160.

SCHEMSKE, D. w. 1983. Breeding system and habitat effects on fitness components in three neotropical Costus (Zingiberaceae). Evolution, 37, 523-539.

SCHOEN, D. J. 1983. Relative fitnesses of selfed and outcrossed progeny in Gilia achilleifolia (Polemoniaceae). Evolution, 37, 292-301.

SHIELDS, W. M. 1987. Dispersal and mating systems: investigating their causal connections. In: Chepko-Sade, B. D. and Halpin, Z. T. (eds) Mammalian Dispersal Patterns: the Effects of Social Structure on Population Genetics, pp. 156213. University of Chicago Press, Chicago.

SMITH, R. H. 1979. On selection for inbreeding in polygynous animals. Heredity, 43, 205-211.

STOCKLEY, P., SEARLE, J. B., MACDONALD, D. W. AND JONES, C. S. 1993. Female multiple mating behaviour in the common shrew as a strategy to reduce inbreeding. Proc. R. Soc. B, 254, 173-179.
TEMPLETON, A. R. 1987. Inferences on natural population structure from genetic studies on captive mammalian populations. In: Chepko-Sade, B. D. and Halpin, Z. T. (eds) Mammalian Dispersal Patterns: the Effects of Social Structure on Population Genetics, pp. 257-272. University of Chicago Press, Chicago.

THORNHILl, N. W. 1993. The Natural History of Inbreeding and Outbreeding: Theoretical and Empirical Perspectives. University of Chicago Press, Chicago.

VAN NOORDWIJK, A. J. AND SCHARLOO, w. 1981. Inbreeding in an island population of the great tit. Evolution, 35, 674688.

VRIJENHOEK, R. C. 1994. Genetic diversity and fitness in small populations. In: Loeschcke, V., Tomiuk, J. and Jain, S. K. (eds) Conservation Genetics, pp. 37-53. Springer, Basel.

WILDT, D. E., BUSH, M., GOODROWE, K. L., PACKer, C., PUSEY, A. E., BROWN, J. L. ET AL. 1987. Reproductive and genetic consequences of founding isolated lion populations. Nature, 329, 328-331.

WILKINSON, L. 1991. SYSTAT: The system for statistics. SYSTAT, Evanston, IL.

WRIGHT, s. 1977. Evolution and the Genetics of Populations, vol. 3, Experimental Results and Evolutionary Deductions. University of Chicago Press, Chicago. 


\section{Appendix}

A list of species, trait type, outbred fitness, inbred fitness values, sample sizes and calculated levels of inbreeding depression for birds, mammals, poikilotherms and plants measured in the wild. Note: $X_{\mathrm{O}}=$ outbred value; $X_{\mathrm{I}}=$ inbred value; outbred $n$ and inbred $n$ are sample sizes; $\delta=1-$ (inbred/outbred); Art.? indicates which species were artificially inbred; $F=$ incidence of inbreeding; Sig.? indicates which estimates of outbred fitness values are significantly greater than inbred fitness values; *indicates that the trait type was inappropriate for the analysis (outbred $<$ inbred), could not be modified and therefore was not used; **indicates that the trait was modified from outbred $<$ inbred to outbred $>$ inbred for the analysis. For traits with more than one entry for $X_{\mathrm{O}}$ and $X_{\mathrm{I}}$, we have calculated a mean $\delta$ estimate for the purpose of the Appendix but used individual estimates for the analysis reported in the text

\begin{tabular}{|c|c|c|c|c|c|c|c|c|c|c|c|}
\hline Species & Trait & $X_{\mathrm{O}}$ & Outbred $n$ & $X_{\mathrm{I}}$ & Inbred $n$ & $F$ & $\delta$ & Art.? & Sig.? & Reference & Comments \\
\hline \multicolumn{12}{|l|}{ Animals } \\
\hline \multicolumn{12}{|l|}{ Birds } \\
\hline Accipiter cooperii & Clutch size & 4 & $?$ & 3.7 & $?$ & & 0.075 & No & $?$ & $\begin{array}{l}\text { Rosenfield \& } \\
\text { Bielefeldt (1992) }\end{array}$ & \\
\hline \multirow[t]{3}{*}{ Aphelocoma ultramarina } & Nest success & $0.363,0.510$ & 625 & $0.344,0.458$ & 32 & & 0.077 & No & No & $\begin{array}{l}\text { Brown \& } \\
\text { Brown (1998) }\end{array}$ & \\
\hline & Brood size & 3.27 & 445 & 2.53 & 24 & & 0.226 & & Yes & & \\
\hline & Nestling survival & 0.33 & 858 & 0.086 & 35 & & 0.739 & & Yes & & \\
\hline \multirow[t]{8}{*}{ Geospiza fortis } & Clutch size & $3.49,3.57$ & 27,8 & $3.50,3.34$ & & $0.085,0.125$ & 0.031 & No & No & $\begin{array}{l}\text { Gibbs \& } \\
\text { Grant (1989) }\end{array}$ & $\begin{array}{l}\text { Total } \\
\text { sample size }\end{array}$ \\
\hline & No. eggs hatched & $2.01,1.92$ & 27,8 & $1.65,1.68$ & & $0.085,0.125$ & 0.152 & & No & & \\
\hline & No. young fledged & $1.67,1.58$ & 27,8 & $1.40,1.52$ & & $0.085,0.125$ & 0.1 & & No & & \\
\hline & No. young surviving & $0.69,0.77$ & 16,6 & $0.52,0.72$ & & $0.085,0.125$ & 0.155 & & No & & \\
\hline & $\%$ eggs hatched & 54,51 & 27,8 & 45,44 & & $0.085,0.125$ & 0.152 & & No & & \\
\hline & $\%$ young fledged & 79,79 & 21,6 & 85,75 & & $0.085,0.125$ & -0.013 & & No & & \\
\hline & $\%$ eggs fledged & 45,41 & 27,8 & 38,36 & & $0.085,0.125$ & 0.139 & & No & & \\
\hline & $\%$ young surviving & 48,51 & 14,5 & 33,39 & & $0.085,0.125$ & 0.274 & & No & & \\
\hline \multirow[t]{2}{*}{ Geospiza magnirostris } & Hatching success & 0.84 & $?$ & 0.73 & $?$ & 0.092 & 0.173 & No & No & $\begin{array}{l}\text { Grant \& } \\
\text { Grant (1995) }\end{array}$ & \\
\hline & Fluctuating asymmetry & -0.068 & 41 & 2.33 & & 0.092 & $?$ & & Yes & & $\begin{array}{l}\text { Total } \\
\text { sample size }\end{array}$ \\
\hline \multirow[t]{11}{*}{ Malurus splendens } & Number of nests & 127 & 107 & 47 & 29 & & 0.63 & No & $?$ & $\begin{array}{l}\text { Rowley } \\
\text { et al. (1986) }\end{array}$ & $\begin{array}{l}\text { No. breeding } \\
\text { pairs }\end{array}$ \\
\hline & Number of eggs & 378 & 107 & 142 & 29 & & 0.62 & & $?$ & & \\
\hline & Number of nestlings & 336 & 107 & 125 & 29 & & 0.63 & & $?$ & & \\
\hline & Number of fledglings & 301 & 107 & 109 & 29 & & 0.64 & & ? & & \\
\hline & Number of yearlings & 115 & 107 & 46 & 29 & & 0.6 & & ? & & \\
\hline & Clutch size & 3 & 107 & 3 & 29 & & 0 & & No & & \\
\hline & Clutches/year/female & 1.7 & 107 & 1.8 & 29 & & -0.06 & & No & & \\
\hline & Nestlings/eggs & 0.89 & 107 & 0.88 & 29 & & 0.01 & & $?$ & & \\
\hline & Fledglings/nestlings & 0.9 & 107 & 0.87 & 29 & & 0.03 & & $?$ & & \\
\hline & Yearlings/fledglings & 0.38 & 107 & 0.42 & 29 & & -0.11 & & No & & \\
\hline & Nestling survival & 79.7 & 107 & 76.8 & 29 & & 0.04 & & No & & \\
\hline Melospiza melodia & Reproductive success & 0.13 & 136 & -0.18 & 8 & & $?$ & No & No & Arcese (1989) & \\
\hline Melospiza melodia & Survival & 135,95 & 230 & 30,5 & 35 & & 0.863 & No & Yes & $\begin{array}{l}\text { Keller } \\
\text { et al. (1994) }\end{array}$ & \\
\hline
\end{tabular}




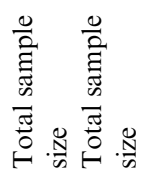

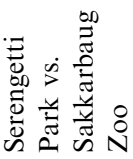

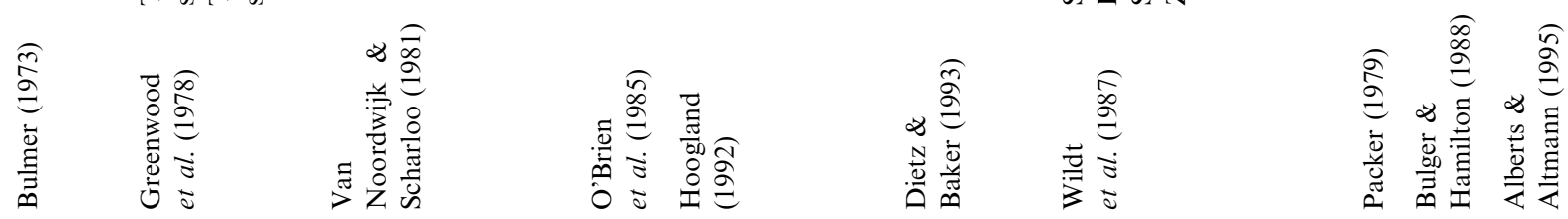

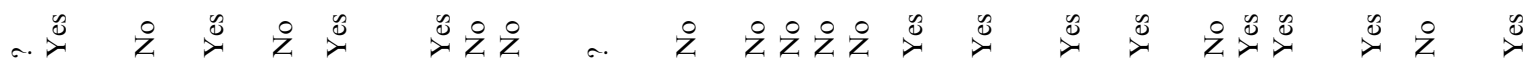

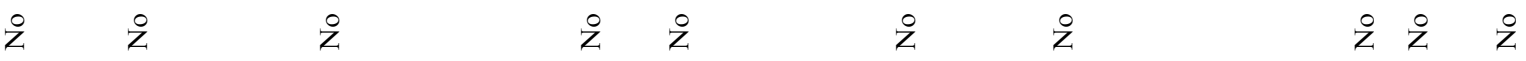

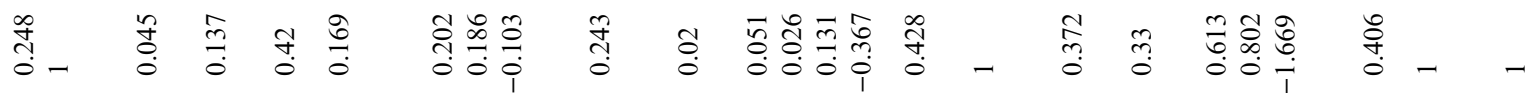

$\infty \underset{ㅇ}{q}$ in 29 .

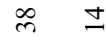
กิ

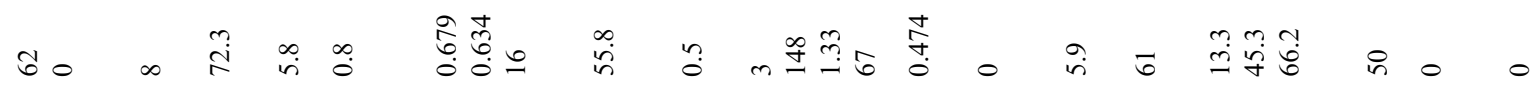

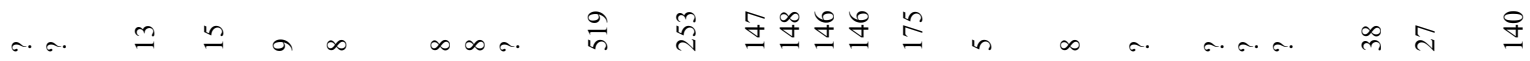

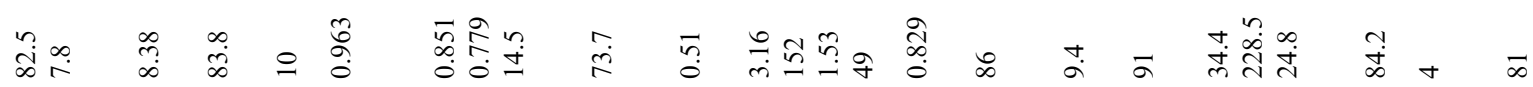

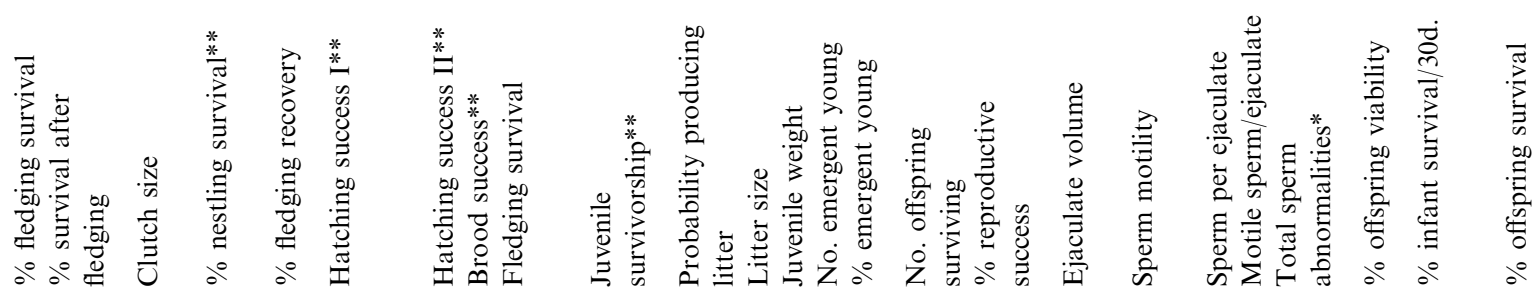<smiles>CCCC</smiles><smiles>CC1[C@@H](C)C[C@@H]1C</smiles>
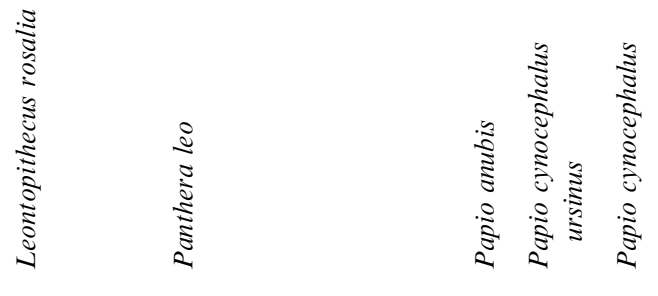


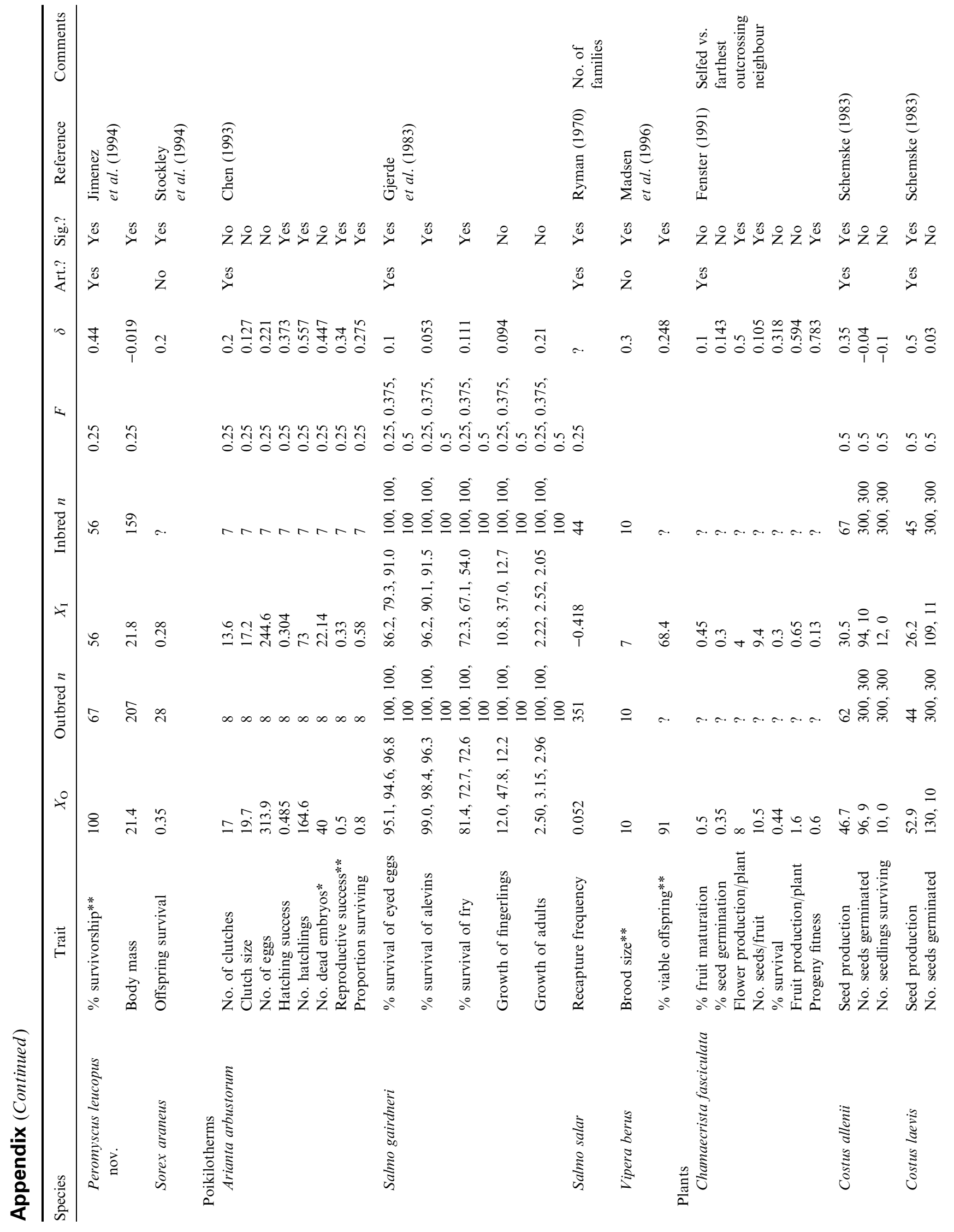

(c) The Genetical Society of Great Britain, Heredity, 83, 260-270. 


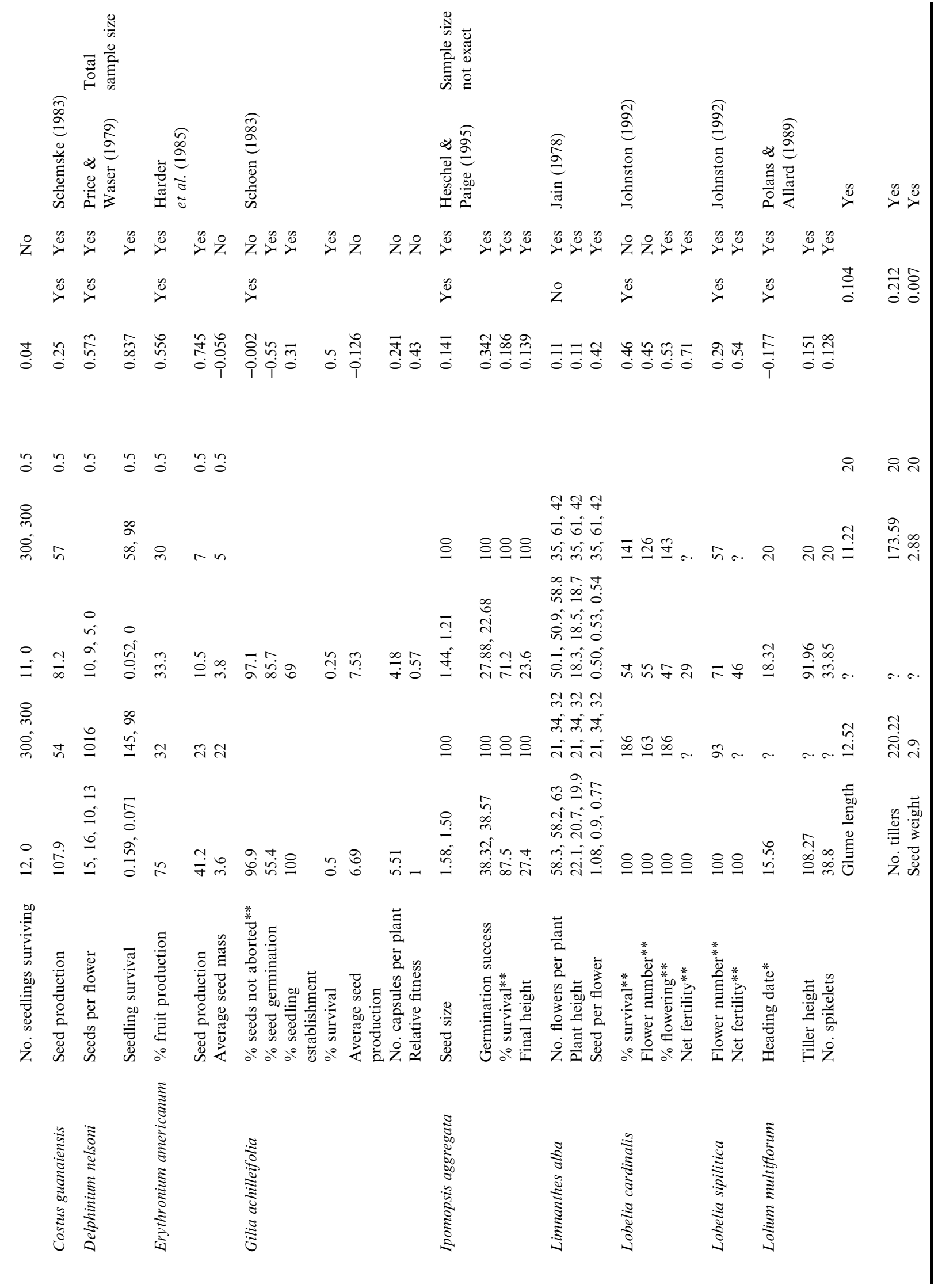

(C) The Genetical Society of Great Britain, Heredity, 83, 260-270. 


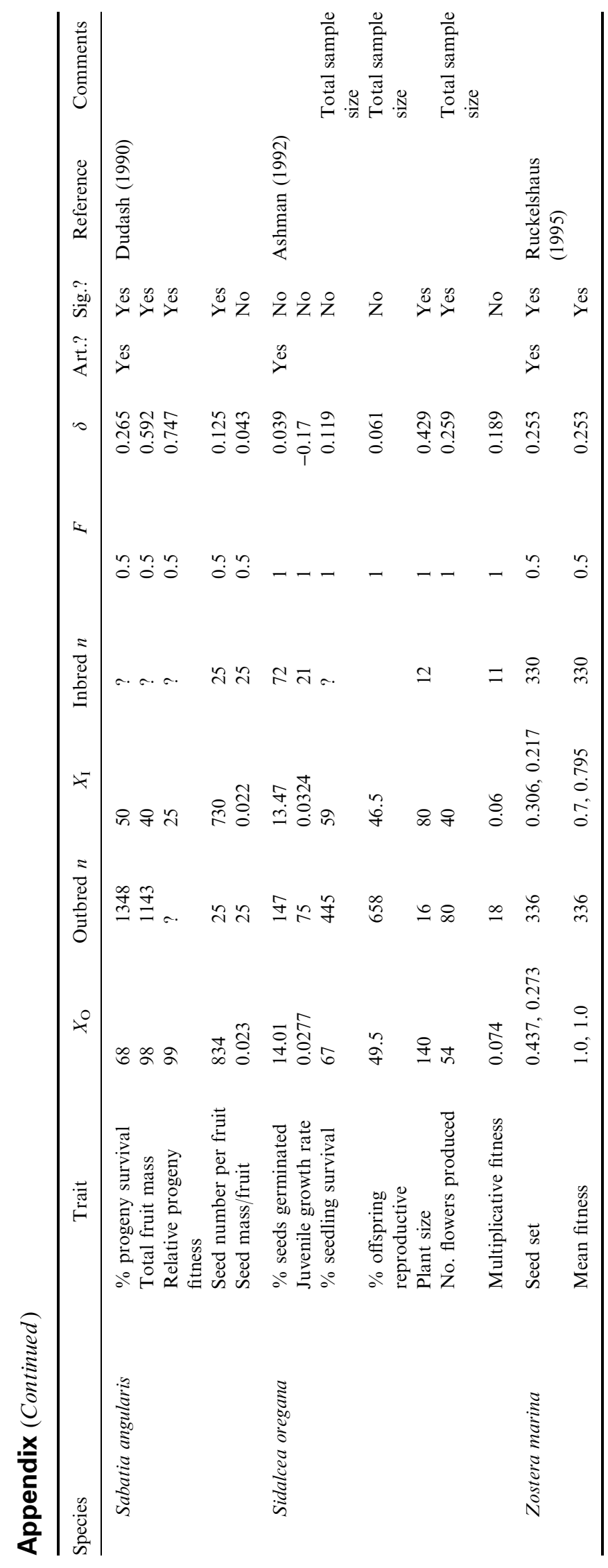

(c) The Genetical Society of Great Britain, Heredity, 83, 260-270. 